\title{
Notes
}

\section{Catalytic Asymmetric Construction of the exo-7-Aryl-6,8-dioxabicyclo[3.2.1]octane Framework of Psoracorylifols B and C Using a Carbonyl Ylide Cycloaddition Strategy ${ }^{\dagger}$}

\author{
Yasunobu Kurosaki, Naoyuki Shimada, Masahiro Anada, Hisanori Nambu, and Shunichi Hashimoto* \\ Faculty of Pharmaceutical Sciences, Hokkaido University, Sapporo 060-0812, Japan. *E-mail: hsmt@pharm.hokudai.ac.jp \\ Received November 28, 2009, Accepted December 5, 2009
}

Key Words: Asymmetric reaction, 1,3-Dipolar cycloaddition, Carbonyl ylides, Chiral dirhodium(II) carboxylates, Aldehydes

Psoracorylifols A-E were isolated from the seeds of Psoralea corylifolia L., which is a well-known traditional Chinese medicine, by Yue and co-workers in 2006. These compounds have been shown to exhibit significant inhibitory activity against two strains of Helicobacter pylori (SS1 and ATCC 43504) at the level of MICs of $12.5 \sim 25 \mu \mathrm{g} / \mathrm{mL}$, especially against $H$. pylori-ATCC 43504, a drug-resistant strain with MIC of $128 \mu \mathrm{g} /$ $\mathrm{mL}$ to resist metroniazole. In 2007, Yoshikawa and co-workers independently isolated psoracorylifols B (1) and C (2), possessing a 6,8-dioxabicyclo[3.2.1] octane ring system, from the same seeds. ${ }^{2}$

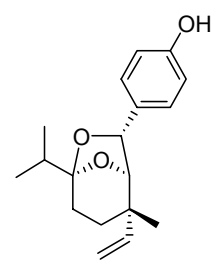

psoracorylifol B (1)

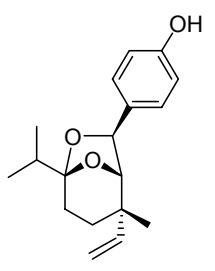

psoracorylifol C (2)
The 6,8-dioxabicyclo[3.2.1] octane skeleton is a common structural subunit in many biologically active natural products. ${ }^{3}$ Among a variety of synthetic routes to such bicyclic ketals, ${ }^{4}$ the dirhodium(II)-catalyzed tandem six-membered cyclic carbonyl ylide formation/1,3-dipolar cycloaddition reaction of $\alpha$-diazo- carbonyl compounds with aldehydes as dipolarophiles ${ }^{5,6}$ is one of the most direct and powerful methods for the construction of this ring system. As a seminal work, Padwa and co-workers reported a concise synthesis of exo- and endo-brevicomins employing the cycloaddition of a six-membered carbonyl ylide derived from 1-diazo-2,5-hexanedione with propionaldehyde in the presence of a catalytic amount of $\mathrm{Rh}_{2}(\mathrm{OAc})_{4} \cdot{ }^{6 \mathrm{~d}, \mathrm{e}}$ Consequently, the development of an enantioselective version of this sequence catalyzed by chiral dirhodium(II) complexes has become a challenging objective. In this process, the chiral dirhodium(II) catalyst must be capable of associating with carbonyl ylide intermediates in the cycloaddition step, ${ }^{7-9}$ because catalystfree carbonyl ylides are achiral. ${ }^{10}$ Recently, we reported catalytic enantioselective 1,3-dipolar cycloadditions of a six-membered carbonyl ylide derived from 1-diazo-5-phenyl-2,5-pentanedione (4a) with aromatic aldehydes 5a-d using dirhodium(II) tetrakis[ $N$-benzene-fused-phthaloyl- $(S)$-valinate], $\mathrm{Rh}_{2}(S \text {-BPTV })_{4}$ (3), in which electron-deficient dipolarophiles such as $\mathbf{5 b}$ and 5c provided exclusively exo cycloadducts 6ab and 6ac in good yields and with up to $92 \%$ ee (Scheme 1). ${ }^{11}$ As a logical extension of our studies, we addressed a catalytic asymmetric construction of the exo-7-aryl-6,8-dioxabicyclo[3.2.1] octane framework of psoracorylifols B (1) and C (2). Herein, we report exoand enantioselective cycloadditions of a six-membered carbonyl ylide derived from 1-diazo-6-methyl-2,5-heptanedione (4b) with aromatic aldehydes under the catalysis of $\mathrm{Rh}_{2}(S \text {-BPTV })_{4}$

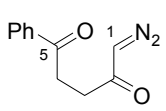

$4 a$
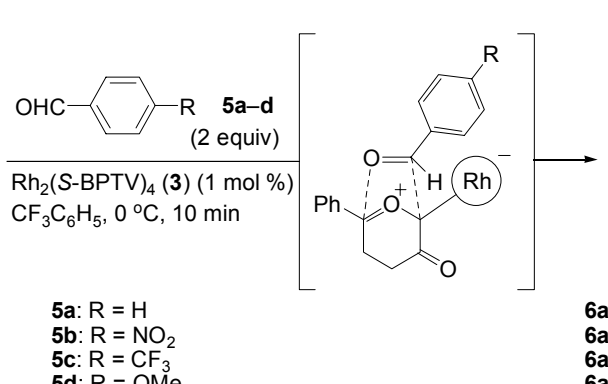

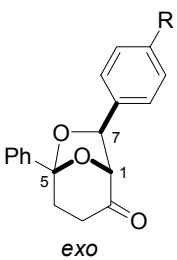

6aa: $\mathrm{R}=\mathrm{H}$

$48 \%(78 \%$ ee $)$ Gac: $R=\mathrm{CF}_{2} \quad 71 \%(92 \%$ ee $)$ Gad: $R=0 \mathrm{M}$ - $69 \%(91 \%$ ee $)$

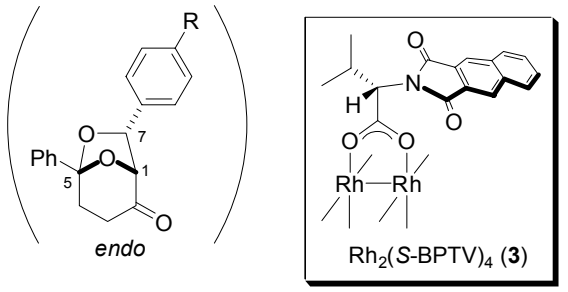

7aa-ad

Not detected

Scheme 1. Enantioselective tandem carbonyl ylide formation/1,3-dipolar cycloaddition of $\mathbf{4 a}$ with $\mathbf{5}$ a-d catalyzed by $\mathrm{Rh}_{2}(S \text {-BPTV })_{4}(\mathbf{3})$

\footnotetext{
${ }^{\dagger}$ This paper is dedicated to Professor Sunggak Kim on the occasion of his honorable retirement.
} 
Table 1. Enantioselective cycloaddition of $\mathbf{4 b}$ with aldehydes $\mathbf{5 a}, \mathbf{b}$, d-h catalyzed by $\mathrm{Rh}_{2}(S \text {-BPTV })_{4}(\mathbf{3})$



${ }^{a}$ Combined yield of 6 and $7 .{ }^{b}$ Determined by ${ }^{1} \mathrm{H}$ NMR analysis of the crude product. ${ }^{c}$ Determined by HPLC (Daicel Chiralpak IC). ${ }^{d}$ Determined by HPLC (Daicel Chiralpak IA). ${ }^{e}$ Determined by HPLC (Daicel Chiralpak AD-H).

(3), in which high levels of asymmetric induction (up to $87 \%$ ee) have been achieved by the use of electron-rich aromatic aldehydes.

On the basis of our previous work, ${ }^{11}$ we initially explored the tandem carbonyl ylide formation/1,3-dipolar cycloaddition reaction of $\mathbf{4 b}$ bearing an isopropyl substituent at $\mathrm{C} 5$ with benzaldehyde (5a) (2 equiv) using $1 \mathrm{~mol} \%$ of $\mathrm{Rh}_{2}(S \text {-BPTV })_{4}$ (3) in benzotrifluoride at $23{ }^{\circ} \mathrm{C}$ (Table 1 , entry 1 ). The reaction proceeded smoothly to completion in less than $5 \mathrm{~min}$, giving exo and endo cycloadducts $6 \mathbf{b a}$ and $7 \mathbf{b a}$ in $62 \%$ combined yield. The assignment of exo and endo cycloadducts was made upon inspection of the ${ }^{1} \mathrm{H}$ NMR spectrum; the ratio of exo cycloadduct $\mathbf{6 b a}$ (singlets at 4.44 and $5.04 \mathrm{ppm}$ for the bridgehead $\mathrm{H} 1$ and benzylic $\mathrm{H} 7$ protons without any coupling) and endo cycloadduct $7 \mathrm{ba}$ (doublets at 4.66 and $5.27 \mathrm{ppm}$ for the bridgehead $\mathrm{H} 1$ and benzylic $\mathrm{H} 7$ protons with a coupling constant of $J=5.4 \mathrm{~Hz}$ ) was determined to be $91: 9$ by ${ }^{1} \mathrm{H}$ NMR analysis of the crude reaction mixture. The enantiomeric excess of the exo isomer 6ba was determined to be $79 \%$ by HPLC using Daicel Chiralpak IC column. Unexpectedly from the results with $\alpha$-diazo ketone 4a bearing a phenyl substituent at $\mathrm{C} 5,{ }^{11}$ switching the dipolarophile from benzaldehyde to $p$-nitrobenzaldehyde (5b) significantly diminished the enantioselectivity for the exo isomer $\mathbf{6 b b}(30 \%$ ee, entry 2$)$, though little variation in combined yield or exo-selectivity was observed.

Since psoracorylifols B (1) and C (2) contain a hydroxy group at the para position on the benzene ring, we next explored the reaction of $4 \mathrm{~b}$ with a variety of protected $p$-hydroxybenzaldehyde derivatives $\mathbf{5 d}$-h as dipolarophiles. We found that the use of electron-poor aromatic aldehydes $\mathbf{5 e}$ and $\mathbf{5} \mathbf{f}$ carrying $p$-mesylate or acetate groups led to slightly lower enantioselectivities than that with benzaldehyde ( $74 \%$ and $77 \%$ ee, entries 3 and 4 ), whereas the reaction with an electron-rich $p$-methoxybenzaldehyde (5d) provided a 94:6 mixture of exo and endo cycloadducts $6 \mathbf{b d}$ and $7 \mathbf{b d}$ in $57 \%$ yield with $87 \%$ ee for $\mathbf{6 b d}$ (entry 6 ). Thus, we then examined the reaction of $p$-hydroxybenzaldehyde derivatives $\mathbf{5 g}$ and $\mathbf{5 h}$ protected as more easily removable methoxymethyl (MOM) or benzyl (Bn) ethers. Gratifyingly, the use of these dipolarophiles $\mathbf{5 g}$ and $\mathbf{5 h}$ afforded the corresponding exo cycloadducts $\mathbf{6 b g}$ and $\mathbf{6 b h}$ in similar good yields and high enantioselectivities as those found with $\mathbf{5 d}(87 \%$ and $86 \%$ ee, entries 7 and 8). While the discrepancy in reaction mode between carbonyl ylide cycloadditions of $4 \mathbf{a}$ and $\mathbf{4 b}$ with aromatic aldehydes remains to be elucidated, it is noteworthy that electron-rich and electron-poor aromatic aldehyde dipolarophiles can complement each other in this type of cycloaddition process.

In summary, we have achieved a highly efficient, catalytic asymmetric construction of the exo-7-aryl-6,8-dioxabicyclo[3.2.1] octane framework of psoracorylifols $\mathrm{B}$ and $\mathrm{C}$ using the 1,3-dipolar cycloaddition reaction of a six-membered carbonyl ylide derived from 1-diazo-6-methyl-2,5-heptanedione with electron-rich aromatic aldehydes under the influence of $\mathrm{Rh}_{2}(S$ BPTV $)_{4}$. This work, together with the previous finding, demonstrates that the extent of asymmetric induction is highly sensitive to both the substitution pattern (aryl or alkyl substituents) at the ylide carbonyl and the electronic nature of aromatic aldehyde dipolarophiles. Further efforts toward the total synthesis of psoracorylifols B and C are currently underway.

\section{Experimental Section}

Representative procedure for the tandem carbonyl ylide formation/1,3-dipolar cycloaddition (entry 7 in Table 1). $\mathrm{Rh}_{2}(S-$ BPTV) 4 -2THF (3.1 mg, $0.002 \mathrm{mmol}, 1 \mathrm{~mol} \%$ ) was added in one portion to a solution of $4 \mathrm{~b}(33.6 \mathrm{mg}, 0.20 \mathrm{mmol})$ and $\mathbf{5 h}$ $(84.9 \mathrm{mg}, 0.40 \mathrm{mmol})$ in benzotrifluoride $(2.0 \mathrm{~mL})$ at $23{ }^{\circ} \mathrm{C}$. After stirring for $5 \mathrm{~min}$, the mixture was concentrated in vacuo. The ratio of $\mathbf{6 b h}$ and $\mathbf{7 b h}$ was determined to be $95: 5$ by ${ }^{1} \mathrm{H}$ NMR of the crude product. The residue was purified by column chromatography (silica gel, 1:2 hexane/benzene $\rightarrow 10: 1$ hexane/ $\mathrm{Et}_{2} \mathrm{O}$ ) to give exo-7-(4-benzyloxyphenyl)-5-isopropyl-6,8-dioxabicyclo[3.2.1] octan-2-one (6bh) $(43.3 \mathrm{mg}, 0.123 \mathrm{mmol}$, $62 \%)$ as a white solid, along with endo isomer $7 \mathbf{b h}(1.6 \mathrm{mg}, 0.04$ mmol, $2 \%$ ) as a white solid. 6bh: TLC $R_{f} 0.21$ (4:1 hexane/ EtOAc); $\mathrm{mp} 51.5 \sim 53.0^{\circ} \mathrm{C}$ for $86 \%$ ee; $[\alpha]_{\mathrm{D}}{ }^{20}-37.5(c 1.01$, $\mathrm{CHCl}_{3}$ ) for $86 \%$ ee; IR (neat) $v 2968,1733,1611,1585,1243$ $\mathrm{cm}^{-1} ;{ }^{1} \mathrm{H}$ NMR $\left(400 \mathrm{MHz}, \mathrm{CDCl}_{3}\right) \delta 1.09(\mathrm{~d}, J=6.9 \mathrm{~Hz}, 3 \mathrm{H}$, $\left.\mathrm{CH}\left(\mathrm{CH}_{3}\right)_{2}\right), 1.10\left(\mathrm{~d}, J=6.9 \mathrm{~Hz}, 3 \mathrm{H}, \mathrm{CH}\left(\mathrm{CH}_{3}\right)_{2}\right), 2.09$ (ddd, $J=$ 4.6, 8.0, $13.8 \mathrm{~Hz}, 1 \mathrm{H}, \mathrm{CH}_{2}$ ), 2.24 (heptet, $J=6.9 \mathrm{~Hz}, 1 \mathrm{H}$, $\left.\mathrm{CH}\left(\mathrm{CH}_{3}\right)_{2}\right), 2.26\left(\mathrm{~m}, 1 \mathrm{H}, \mathrm{CH}_{2}\right), 2.54$ (dddd, $J=1.2,4.6,8.0$, $16.0 \mathrm{~Hz}, 1 \mathrm{H}, \mathrm{COCH}_{2} \mathrm{C}$ ), 2.61 (ddd, $J=8.0,8.0,16.0 \mathrm{~Hz}, 1 \mathrm{H}$, $\left.\mathrm{CH}_{2}\right), 4.41(\mathrm{~s}, 1 \mathrm{H}, \mathrm{COCH}), 4.98(\mathrm{~s}, 1 \mathrm{H}, \mathrm{ArCH}), 5.06(\mathrm{~s}, 2 \mathrm{H}$, $\left.\mathrm{PhCH}_{2} \mathrm{O}\right), 6.95(\mathrm{~d}, J=8.6 \mathrm{~Hz}, 2 \mathrm{H}, A r), 7.29(\mathrm{~d}, J=8.6 \mathrm{~Hz}, 2 \mathrm{H}$, $A r), 7.32-7.43(\mathrm{~m}, 5 \mathrm{H}, A r) ;{ }^{13} \mathrm{C}$ NMR $\left(100 \mathrm{MHz}, \mathrm{CDCl}_{3}\right) \delta 17.6$ $\left(\mathrm{CH}_{3}\right), 17.9\left(\mathrm{CH}_{3}\right), 28.7\left(\mathrm{CH}_{2}\right), 32.5\left(\mathrm{CH}_{2}\right), 35.6(\mathrm{CH}), 70.0$ $\left(\mathrm{CH}_{2}\right), 79.4(\mathrm{CH}), 86.4(\mathrm{CH}), 112.6(\mathrm{C}), 114.8(\mathrm{CH}), 127.4$ $(\mathrm{CH}), 127.6(\mathrm{CH}), 128.0(\mathrm{CH}), 128.6(\mathrm{CH}), 132.5(\mathrm{C}), 136.8$ 
(C), 158.7 (C), 206.7 (C); EI-HRMS calcd for $\mathrm{C}_{22} \mathrm{H}_{24} \mathrm{O}_{4}\left(\mathrm{M}^{+}\right)$ 352.1675, found 352.1673. 7bh: TLC $R_{f} 0.30$ (4:1 hexane/ EtOAc); ${ }^{1} \mathrm{H}$ NMR $\left(400 \mathrm{MHz}, \mathrm{CDCl}_{3}\right) \delta 1.11(\mathrm{~d}, J=7.3 \mathrm{~Hz}, 3 \mathrm{H}$, $\left.\mathrm{CH}\left(\mathrm{CH}_{3}\right)_{2}\right), 1.12\left(\mathrm{~d}, J=7.3 \mathrm{~Hz}, 3 \mathrm{H}, \mathrm{CH}\left(\mathrm{CH}_{3}\right)_{2}\right), 2.11-2.22(\mathrm{~m}$, $\left.4 \mathrm{H}, \mathrm{CH}_{2}, \mathrm{CH}\left(\mathrm{CH}_{3}\right)_{2}\right), 2.37\left(\mathrm{~m}, 1 \mathrm{H}, \mathrm{CH}_{2}\right), 4.61$ (dd, $J=1.4,5.4$ $\mathrm{Hz}, 1 \mathrm{H}, \mathrm{COCH}), 5.03\left(\mathrm{~s}, 2 \mathrm{H}, \mathrm{PhCH}_{2} \mathrm{O}\right), 5.21(\mathrm{~d}, J=5.4 \mathrm{~Hz}$, $1 \mathrm{H}, \mathrm{ArCH}), 6.93(\mathrm{~d}, J=8.6 \mathrm{~Hz}, 2 \mathrm{H}, A r), 7.23(\mathrm{~d}, J=8.6 \mathrm{~Hz}$, 2H, $A r)$, 7.33-7.43 (m, 5H, Ar).

The enantiomeric excess of $6 \mathrm{bh}$ was determined to be $86 \%$ by HPLC using a Daicel Chiralpak AD-H column (19:1 hexane/ 2-propanol, flow rate: $1.0 \mathrm{~mL} / \mathrm{min}$; detection: $230 \mathrm{~nm}$ ): retention time: $14.4 \mathrm{~min}$ (major enantiomer), $17.3 \mathrm{~min}$ (minor enantiomer).

Acknowledgments. This research was in part supported by a Grant-in-Aid for Scientific Research from Japan Society for the Promotion of Science (JSPS).

\section{References}

1. Yin, S.; Fan, C.-Q.; Dong, L.; Yue, J.-M. Tetrahedron 2006, 62, 2569.

2. Matsuda, H.; Sugimoto, S.; Morikawa, T.; Matsuhira, K.; Mizuguchi, E.; Nakamura, S.; Yoshikawa, M. Chem. Pharm. Bull. 2007, $55,106$.

3. Milroy, L.-G.; Zinzalla, G.; Prencipe, G.; Michel, P.; Ley, S. V.; Gunaratnam, M.; Beltran, M.; Neidle, S. Angew. Chem. Int. Ed. 2007, 46, 2493 and references cited therein.

4. For reviews, see: (a) Mundy, B. P.; Lipkowitz, K. B.; Dirks, G. W. Heterocycles 1977, 6, 51. (b) Mori, K. Tetrahedron 1989, 45, 3233. (c) Kotsuki, H. Synlett 1992, 97. (d) Jun, J.-G. Synlett 2003, 1759.

5. For books and reviews, see: (a) Padwa, A. Acc. Chem. Res. 1991, 24, 22. (b) Padwa, A.; Hornbuckle, S. F. Chem. Rev. 1991, 91, 263. (c) Padwa, A.; Krumpe, K. E. Tetrahedron 1992, 48, 5385. (d) Padwa, A.; Weingarten, M. D. Chem Rev 1996, 96, 223. (e) Doyle, M. P.; McKervey, M. A.; Ye, T. Modern Catalytic Methods for Organic Synthesis with Diazo Compounds; Wiley-Interscience: New York, 1998; Chapter 7. (f) Mehta, G.; Muthusamy, S. Tetrahedron 2002, 58, 9477. (g) McMills, M. C.; Wright, D. In Synthetic Applications of 1,3-Dipolar Cycloaddition Chemistry Toward Heterocycles and Natural Products; Padwa, A., Pearson, W. H., Eds.; John Wiley \& Sons: Hoboken, 2003; Chapter 4. (h) Savizky, R. M.; Austin, D. J. In Modern Rhodium-Catalyzed Organic Reactions; Evans P. A., Ed.; Wiley-VCH: Weinheim, 2005; Chapter 19. (i) Padwa, A. Helv. Chim. Acta 2005, 88, 1357. (j) Padwa, A. J. Organomet. Chem. 2005, 690, 5533.

6. For tandem carbonyl ylide formation/1,3-dipolar cycloadditions of $\alpha$-diazocarbonyl compounds with aldehydes catalyzed by achiral dirhodium(II) complexes, see: (a) de March, P.; Huisgen, R. J. Am. Chem. Soc. 1982, 104, 4952. (b) Padwa, A.; Fryxell, G. E.; Zhi, L. J. Org. Chem. 1988, 53, 2875. (c) Padwa, A.; Chinn, R. L.; Hornbuckle, S. F.; Zhi, L. Tetrahedron Lett. 1989, 30, 301. (d) Padwa, A.; Chinn, R. L.; Zhi, L. Tetrahedron Lett. 1989, 30, 1491. (e) Padwa, A.; Fryxell, G. E.; Zhi, L. J. Am. Chem. Soc. 1990, 112, 3100. (f) Padwa, A.; Chinn, R. L.; Hornbuckle, S. F.; Zhang, Z. J. J. Org. Chem. 1991, 56, 3271. (g) Alt, M.; Maas, G. Tetrahedron 1994, 50, 7435. (h) Koyama, H.; Ball, R. G.; Berger, G. D. Tetrahedron Lett. 1994, 35, 9185. (i) Hodgson, D. M.; Bailey, J. M.;
Harrison, T. Tetrahedron Lett. 1996, 37, 4623. (j) Drew, M. G. B.; Fengler-Veith, M.; Harwood, L. M.; Jahans, A. W. Tetrahedron Lett. 1997, 38, 4521. (k) Doyle, M. P.; Forbes, D. C.; Protopopova, M. N.; Stanley, S. A.; Vasbinder, M. M.; Xavier, K. R. J. Org. Chem. 1997, 62, 7210. (1) Hodgson, D. M.; Villalonga-Barber, C. Tetrahedron Lett. 2000, 41, 5597. (m) Hodgson, D. M.; Bailey, J. M.; Villalonga-Barber, C.; Drew, M. G. B.; Harrison, T. J. Chem. Soc., Perkin Trans. 1 2000, 3432. (n) Jiang, B.; Zhang, X.; Luo, Z. Org. Lett. 2002, 4, 2453. (o) Muthusamy, S.; Babu, S. A.; Gunanathan, C.; Ganguly, B.; Suresh, E.; Dastidar, P. J. Org. Chem. 2002, 67, 8019. (p) Lu, C.-D.; Chen, Z.-Y.; Liu, H.; Hu, W.-H.; Mi, A.-Q. Org. Lett. 2004, 6, 3071. (q) Russell, A. E.; Brekan, J.; Gronenberg, L.; Doyle, M. P. J. Org. Chem. 2004, 69, 5269. (r) Muthusamy, S.; Krishnamurthi, J.; Nethaji, M. Tetrahedron Lett. 2004, 45, 6485. (s) Muthusamy, S.; Gnanaprakasam, B. Tetrahedron 2005, 61, 1309. (t) DeAngelis, A.; Panne, P.; Yap, G. P. A.; Fox, J. M. J. Org. Chem. 2008, 73, 1435.

7. For a review, see: (a) Hodgson, D. M.; Pierard, F. Y. T. M.; Stupple, P. A. Chem. Soc. Rev. 2001, 30, 50. Hodgson and co-workers were the first to demonstrate high levels of asymmetric induction (up to $90 \%$ ee) in intramolecular cycloaddition of carbonyl ylides derived from unsaturated $\alpha$-diazo- $\beta$-ketoesters using binaphtholphosphate catalyst $\mathrm{Rh}_{2}(R$-DDBNP) 4 . (b) Hodgson, D. M.; Stupple, P. A.; Johnstone, C. Tetrahedron Lett. 1997, 38, 6471. (c) Hodgson, D. M.; Stupple, P. A.; Johnstone, C. Chem. Commun. 1999, 2185. (d) Hodgson, D. M.; Stupple, P. A.; Pierard, F. Y. T. M.; Labande, A. H.; Johnstone, C. Chem. Eur. J. 2001, 7, 4465. (e) Hodgson, D. M.; Brückl, T.; Glen, R.; Labande, A. H.; Selden, D. A.; Dossetter, A. G.; Redgrave, A. J. Proc. Natl. Acad. Sci. U. S. A. 2004, 101, 5450 .

8. Doyle and co-workers reported that the tandem intermolecular carbonyl ylide formation/cycloaddition of ethyl diazoacetate with $p$-nitrobenzaldehyde in the presence of the chiral dirhodium(II) carboxamidate catalyst $\mathrm{Rh}_{2}(4 S \text {-MEOX })_{4}$ afforded the all-cis trisubstituted 1,3-dioxolane as the major product with $28 \%$ ee. Doyle, M. P.; Forbes, D. C. Chem. Rev. 1998, 98, 911.

9. We reported the first successful example of intermolecular cycloadditions of carbonyl ylides derived from $\alpha$-diazo ketones with dimethyl acetylenedicarboxylate, in which $\mathrm{Rh}_{2}(S \text {-BPTV })_{4}(3)$ proved to be the catalyst of choice for achieving enantioselectivities of up to $92 \%$ ee. (a) Kitagaki, S.; Anada, M.; Kataoka, O.; Matsuno, K.; Umeda, C.; Watanabe, N.; Hashimoto, S. J. Am. Chem. Soc. 1999, 121, 1417. (b) Kitagaki, S.; Yasugahira, M.; Anada, M.; Nakajima, M.; Hashimoto, S. Tetrahedron Lett. 2000, 41, 5931. (c) Shimada, N.; Anada, M.; Nakamura, S.; Nambu, H.; Tsutsui, H.; Hashimoto, S. Org. Lett. 2008, 10, 3603.

10. Suga and co-workers developed a conceptually different approach and demonstrated highly enantioselective 1,3-dipolar cycloadditions of 2-benzopyrylium-4-olate generated from the $\mathrm{Rh}_{2}(\mathrm{OAc})_{4}$ catalyzed decomposition of $o$-methoxycarbonyl- $\alpha$-diazoacetophenone with several benzyloxyacetaldehyde derivatives using $\mathrm{Sc}(\mathrm{III})-\mathrm{Pybox}-i$-Pr complex as a chiral Lewis acid catalyst, in which endo cycloadducts were obtained as the major product in up to $93 \%$ ee. (a) Suga, H.; Inoue, K.; Inoue, S.; Kakehi, A. J. Am. Chem. Soc. 2002, 124, 14836. (b) Suga, H.; Inoue, K.; Inoue, S.; Kakehi, A.; Shiro, M. J. Org. Chem. 2005, 70, 47. (c) Suga, H.; Ishimoto, D.; Higuchi, S.; Ohtsuka, M.; Arikawa, T.; Tsuchida, T.; Kakehi, A.; Baba, T. Org. Lett. 2007, 9, 4359.

11. Tsutsui, H.; Shimada, N.; Abe, T.; Anada, M.; Nakajima, M.; Nakamura, S.; Nambu, H.; Hashimoto, S. Adv. Synth. Catal. 2007, 349,521 . 